\title{
Social Evils - From Unemployment to Idleness to Prejudice. Some Suggestions for Mapping the Modern Equivalents of These Old Evils onto New Injustices
}

\author{
DANNY DORLING \\ University of Sheffield*
}

\begin{abstract}
In the midst of World War II the economist William Beveridge christened five social evils, all to be eradicated in Britain: ignorance, want, idleness, disease and squalor. Although Britain took its lead from developments elsewhere, to an extent that would have been hard to imagine in the 1930s, the very worst manifestations of each of these five evils had been overcome by the 1970s. However, from then onwards each evil transformed its appearance. In this paper I briefly argue that the new form of the five had features respectively of revised elitism, exclusion, prejudice, despair and greed.
\end{abstract}

Keywords: Ignorance, Want, Idleness, Disease, Squalor, Elitism, Exclusion, Prejudice, Despair and Greed

JEL Classifications: B5, N01, R11, O20, A13

\section{Introduction}

It was in 1942 that William Beveridge, an economist by reputation, christened the five social evils as: ignorance, want, idleness, disease and squalor. For eradication these respectively required providing universal secondary education to children; extending social security to all; providing near full employment; a national health service; and housing fit for children to be brought up and out of, and for the old to grow old in. A welfare state was required. Just such a state had been introduced earlier in New Zealand and parts of the now standard European model could be found in various places around the rest of the world. However, it was in Britain that the first large scale experiment in eradicating social evil, without revolution, took place (see Figure 1).

In Figure 1 the worst manifestation of ignorance is depicted as bigoted small mindedness; want is depicted as starvation; idleness as lethargy; disease as tuberculosis; and squalor as

\footnotetext{
* Danny Dorling is grateful to Anna Barford for comments on an earlier draft and to Dr Theodore Panagiotidis and Dr Dimitris Ballas for the invitation to speak at the Regional studies Localisation, Labour and Unemployment research Network Seminar at the University of Macedonia, Thessaloniki, Greece on 31st October 2008. This paper is based on that conference presentation.

(C) 2009 Danny Dorling. Licensed under the Creative Commons Attribution - Noncommercial 3.0 Licence (http://creativecommons.org/licenses/by-nc/3.0/. Available at http://rofea.org.
} 
destitution. This paper is concerned with presenting an argument that, although the very worse manifestations of each of these great social evils were largely overcome by the 1970s, new evils began to appear in their place. A suggestion for what each of these new five might be follows. A rechristening from evils to injustices is suggested in conclusion, drawing a few more parallels with the past. The paper ends by suggesting that we now have the advantage of learning from that past, and physical resources now that our parents lacked. As the nature of evils has changed to injustice increasingly we hold all the solutions in our hands. It is not for want of wealth that people suffer in affluent nations, but for want of imagination.

Figure 1: Popular Concepts of the Great Social Evils as They Afflicted Men in 1942

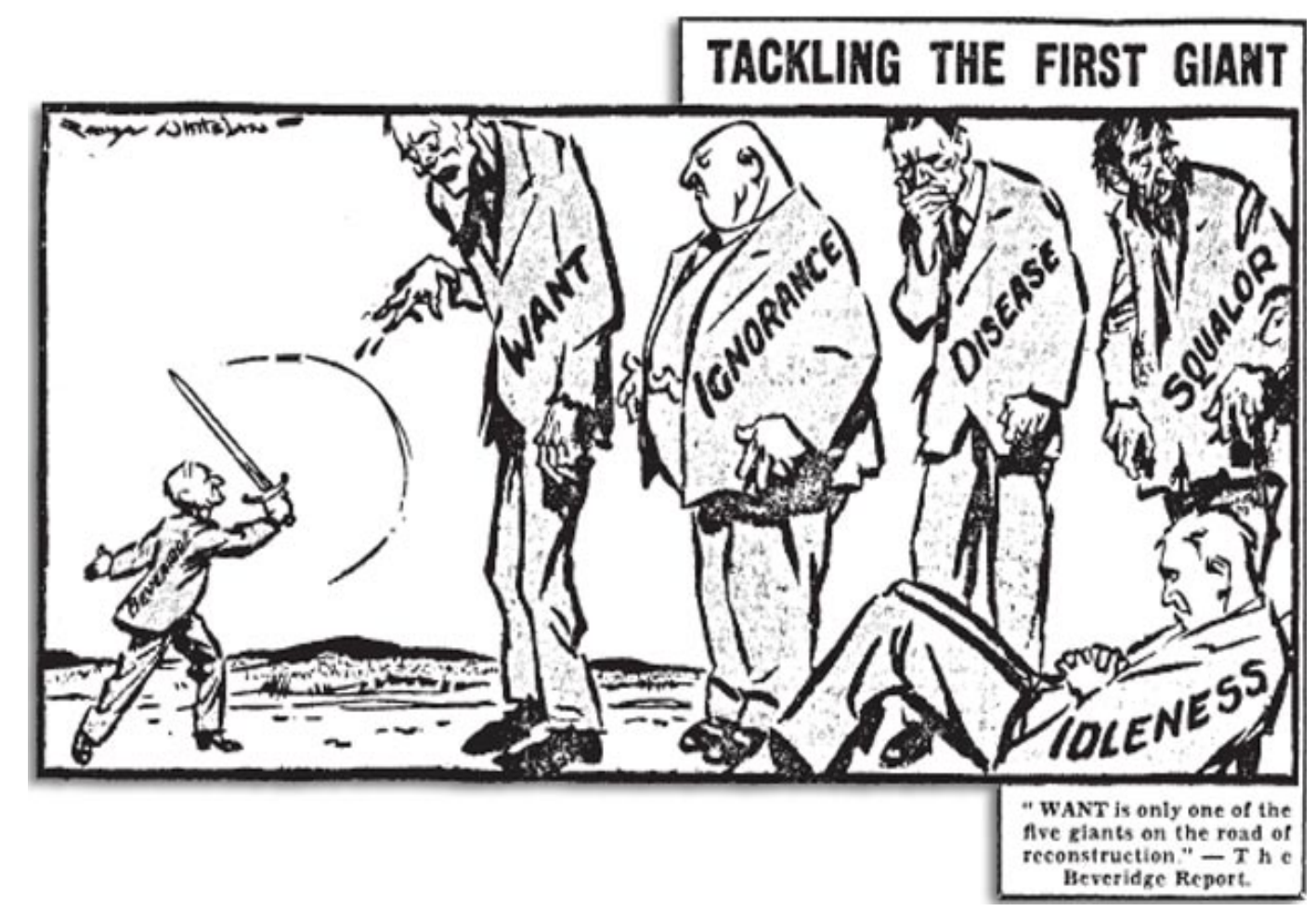

Source: Cartoon is used in the Open University’s K100_9 'unit’ (open access).

\section{Elitism}

The headline in Figure 2 was taken from the website of a British University before the results of the 2008 Research Assessment Exercise were announced (so you won't find its exact equivalent now). It is typical of the kind of marketing which people running British Universities now consider essential to their success. In 1942 this would have been unimaginable. 
Figure 2: A Typical Banner Headline from a British University Website (2008)

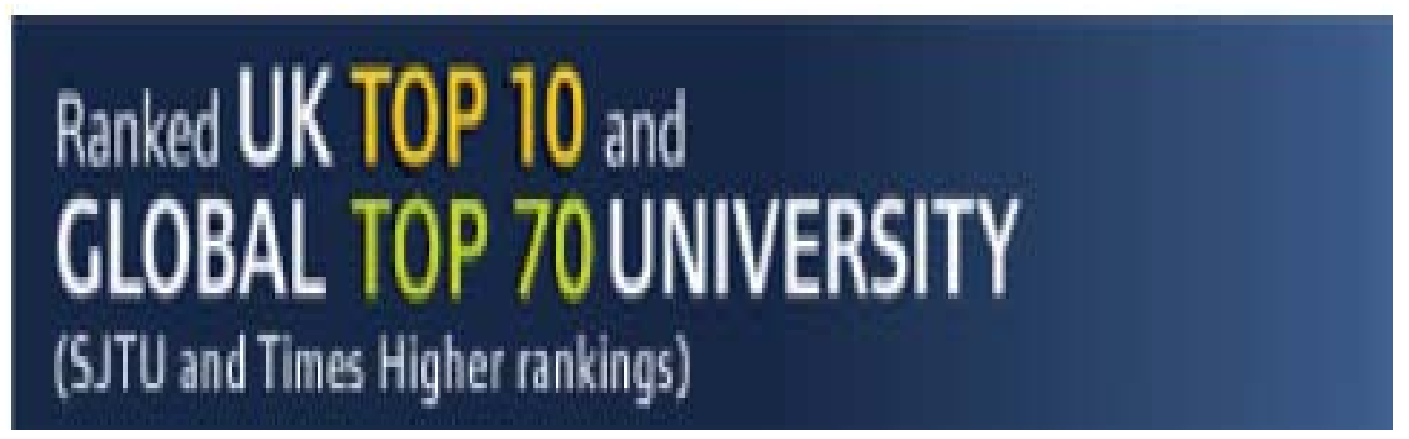

Source: Ironically, any one of a couple of dozen British Universities has this kind of banner.

The university in which I gave the talk this paper is based on has a far more subdued and far less embarrassing banner to be seen on entering its website. It is shown as Figure 3 below. Brass elitism and unwarranted claims to be supreme are not a necessity of modern university life, at least not where universities serve local populations more and are not aimed at selling a myth to overseas students.

Figure 3: A Typical Banner Headline from a Greek University Website (2008)
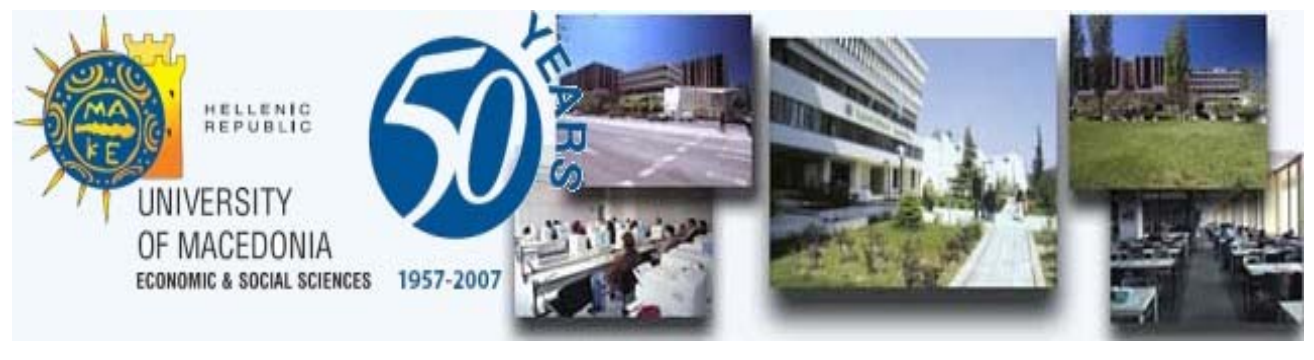

Source: University of Macedonia Economic and Social Sciences website

It is in the more unequal of affluent countries that the transformed evil of ignorance elitism - has reared its head most clearly. By 1942 in Britain those in positions of power (such as William Beveridge) were all too aware of what was occurring elsewhere in Europe, the genocide that, for a single instance, robbed the city which the University of Macedonia is based in of one of the largest Jewish communities in the world (Mazower 2004).

Like many of his contemporaries, and especially economists, William Beveridge was drawn towards eugenic ideas in the 1920s and 30s: ideas of survival of the fittest, the efficiency of competition, allowing the hindmost to fall. However, there is not even the faintest hint of such thoughts in the report of 1942 which in popular British memory bares his 
name. It was thus partly because of the greater evil of fascism in Europe that social evils in Britain came to be addressed so comprehensively in the late 1940s and 50s. The more recent memory of dictators in Greece (1967-74) may well have made it hard there to move towards banal elitism as rapidly as Britain did in the 1980s and 1990s. The geographical distance of the United States from 1930s and 40s fascism may well have made forgetting far easier there and prevented the establishment of a welfare state there in the first place. New social evils emerge when we forget our past.

In Britain the first Prime Minister of the Twenty-first Century showed every sign of never having quite known what is was we were in danger of forgetting. When it came to education he claimed in 2005 that “...we know what works ... push them right throughout ... until the young children ... get the chance to make the most of their God given potential” (Ball 2008) (page 12). The idea that different children have different levels of potential, whether given as a gift by god, dictated through genes, or otherwise bestowed variably, is an idea that grew most strongly under fascism. The reincarnation, as we now forget in Britain, is that school teachers are today being asked to single out pupils who appear especially gifted and talent. When they did this recently, Black pupils "were 'five times less likely to be registered as 'gifted and talented'” than White according to the Independent on Sunday's release of an unpublished Department for Education and Schools report in December 2006 (ibid page 173).

\section{Exclusion}

The rise in elitist views in affluent countries that forgot their past was strongest in those which came to have the greatest inequalities in income and wealth by the late 1980s and throughout the 1990s. It was in these countries, in The United States, Great Britain, Portugal, and New Zealand, that people were most likely to become excluded from the norms of society by no longer being able to afford to be included (Wilkinson and Pickett 2009). It was in these countries too that a small group of the most affluent also found themselves drifting off away from the norms of society, no longer even thinking of sending their children to the same schools as others, nor having holidays that in any way resembled the norm, nor having salaries that bore any resemblance or relationship to national averages, nor relying on the same health services as others, nor using the same kinds of cars, homes, even clothes. In place of want (the old evil of poverty) came exclusion. Few in affluent countries outside of the United States went hungry anymore. The poor became, for the first time in history, more likely to be obese than the rich. But as far as we can tell at no other time had so many people in countries like the United Kingdom not felt part of the societies there (Dorling 2007).

Just before Christmas 2007 hedge fund managers in the city of London circulated on the web the cartoon of their city shown in Figure 4. Pride comes before a fall, and the financial markets of London collapsed in the months that followed. However, the concept that some 


\section{DORLING Social Evils}

could be excluded (or exclude themselves) by dint of some lack of ability (or some great potential they held) did not disappear with that collapse.

Figure 4: Picture Doing the Rounds at London's Private Equity Houses

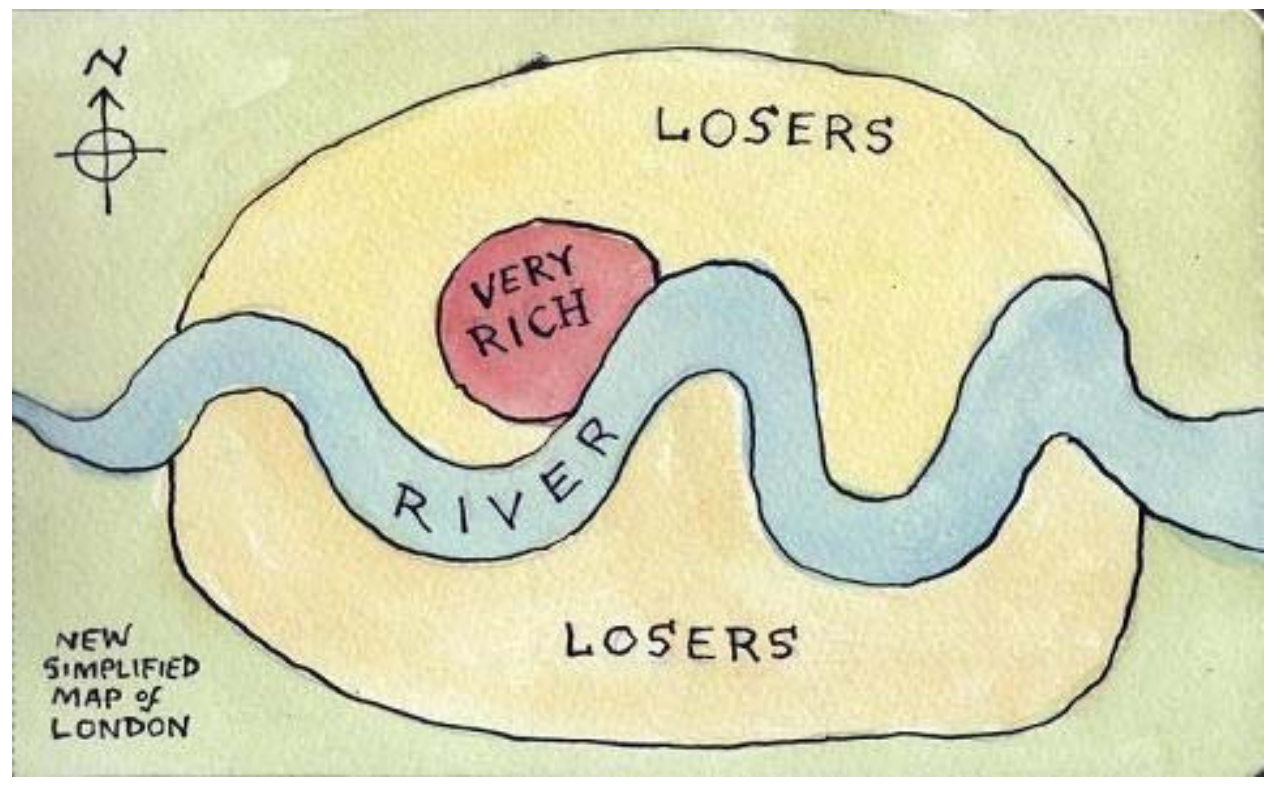

Source:http://anglonoelnatter.blogspot.com/2007/12/intra-contradictions-of-capitalismpart.html (accessed Saturday 15 December 2007).

In the first years of the current century, apparently with almost complete amnesia over the past, with increasing frequency, banal and unsubstantiated claims to inherited differences in ability became common in policy circles in the more unequal of affluent nations. In Britain a single report was cited in one research briefing which suggested that: "There is a wide consensus that the difference in personality between individuals is 30 to 50 per cent determined by genes and 50 to 70 per cent determined by environment and experience ..." (Dixon 2005) (page 11). That 'wide consensus' turned out to be a single reference to a dubious piece of research that has been rubbished elsewhere. However, when an idea becomes an article of faith, only one source, one holy document, is needed, along with faith, to sustain that idea. Evil ideas such that people are of (inherited) inherently differing potentials, sheep and goats, some destined to be discarded, others to lead, are ideas that arise out of (and can cause) fear and ignorance.

In unequal affluent countries there has been a resurgence of the misguided fear of a genetically damaged underclass rising: "Parents whose children were known to have the genotype could be offered voluntary parenting classes” (ibid, page 18). A year or so after that 
reference was made to a mythical genotype of bad behaviour, identical ideas coded in similar words were coming out of the mouth of the British Prime Minister who said “...instead of waiting until the child goes off the rails, we should act early enough ... This is not stigmatizing the child or the family. It may be the only way to save them and the wider community...” (Ball, 2008, page 154). These words came out of his mouth because they were written by his speechwriter's pen. They may well have been written by the pen because the writer read a briefing report or two. The briefing reports may well have said what they said because they were sponsored by a man who believes he was superior and others inferior and he funded the briefing to be written. He may have come to believe this because he was badly taught and later brought up in a society were inequalities had been deliberately fostered and allowed to rise. That occurred because we forgot our past, we forgot what occurs once you allow private prejudices to grow and hold sway.

\section{Prejudice}

As the old evil of ignorance metamorphosed to elitist believes in a revised IQism, and want transformed into the evil of exclusion through a geneticist faith, idleness was replaced by a more general evil of prejudice. The old evil of idleness had been the callousness of allowing millions of people to stand idle, hungry and angry, because a belief in free market solutions was stronger than the evidence of your eyes seeing the lengths of 1930s dole queues. Fascism in Europe grew strong out of that callousness which was another reason why the welfare state brought in after the war was so carefully constructed. It was as much a protection against such horrors repeating as an attempt to be more just. Again though we forget, in Britain a series of accountants, bankers, and economic advisors were given control of policy direction across almost all of government in the early years of the current century. Education policy was suggested by the report of a man, Alex Leich, whose background was not teaching but accounting; housing policy by a woman, Kate Barker who had been an economist for Ford motors, and social security policy to a banker: David Freud. Before the reputation of these professions was severely dented by the collapse of 2008 it had become commonplace in Anglophone countries to see bankers as having the 'best brains'. Too few imagined that it was not through great acumen that they made their money.

It is hard now to remember the bravado of those years and the arrogance of the bankers put in charge of policy, but it is important not to forget. The man put in charge of trying to reduce the continued mass idleness of working age people in Britain, mostly idle because they were sick, mostly sick because they were depressed, wrote in his main report that: "I have considered whether it would be helpful to have an 'ultimate sanction' for jobseekers, in the form of a programme similar to the Australian 'work for the dole'. The evidence suggests that the costs may outweigh its benefits as a labour market measure, and therefore I recommend that the Government continues to look at the experience in Australia but does not, for the 


\section{DORLING Social Evils}

moment, implement something similar.” (Freud 2007) (page 91). The government continued to listen to Mr David Freud even after a change of Prime Minister in 2007. It is unclear whether David changed his mind, or some other appointee, inspired by the idea, thought it good, but by late 2008 the ultimate sanction was being applied to force people to labour against their will, a situation not that distant from slavery. It is all the more stunning that this was done just at the point when unemployment in Britain was rising at its fastest rate for decades (BBC 2008). For those who have free market faith, however, what they see with their eyes is just a distraction sent to tempt them away from the true path, from the way and the light of economic efficiency.

A prejudice that some need to be forced to labour and others rewarded greatly for their effort is not a new prejudice. Neither is the prejudice that Britain is a well ordered and happy family of workers in their place as George Cruikshank's beehive of 1867 was drawn to suggest (see Figure 5). That picture, with bankers holding all up from below, and god's representative on earth (the queen) atop, was drawn to suggest there was no need to give most working men the vote.

Figure 5: The British Beehive by George Cruikshank - Who Needs the Vote?

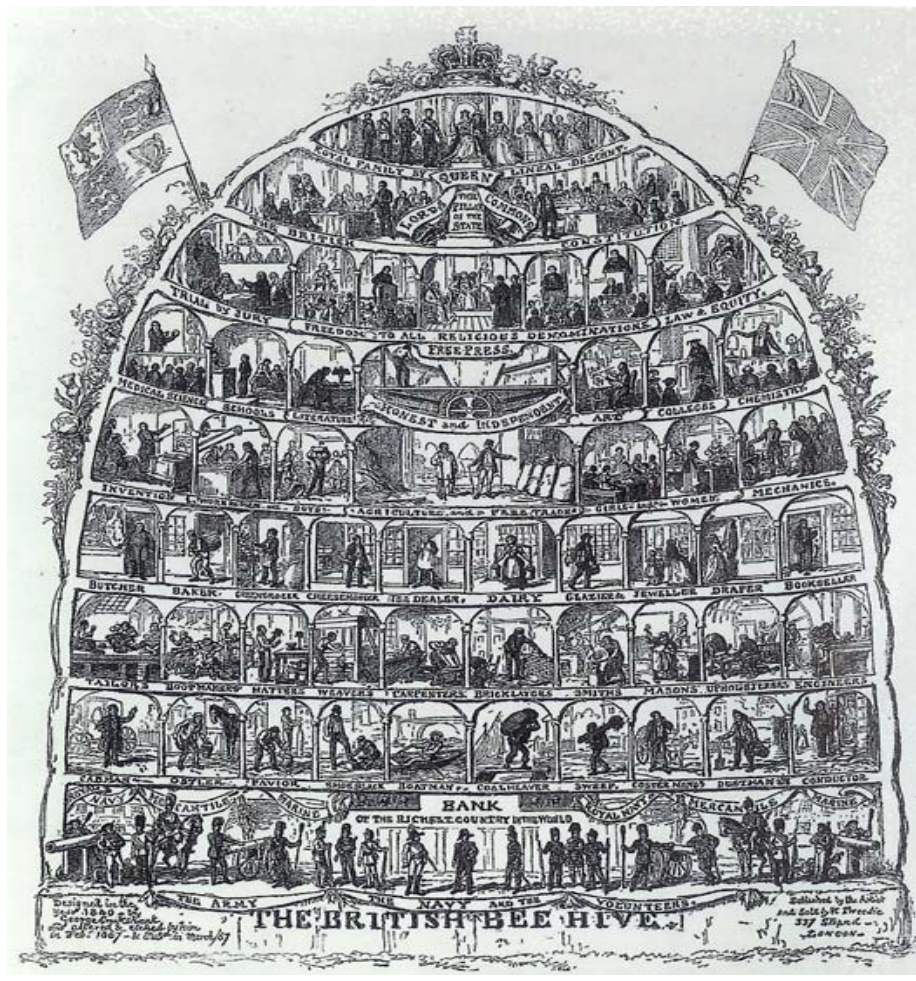

Source: http://www.historyhome.co.uk/peel/politics/beehive.htm 
Now 'even' women have the vote, but it is still the belief of those who control the purse strings that those who work are not to be trusted with thinking too much about how they should be governed. When it looked as if the new British Prime Minister, Gordon Brown, might have begun to move away from David Freud's ideas, the main alternative political party made approaches to the banker (Wintour and Curtis 2008), and he was rapidly reincorporated into the governing party's fold (Toynbee 2008).

Figure 6: Eleven Generations from the Icelandic Family Tree, a Genome Sold.

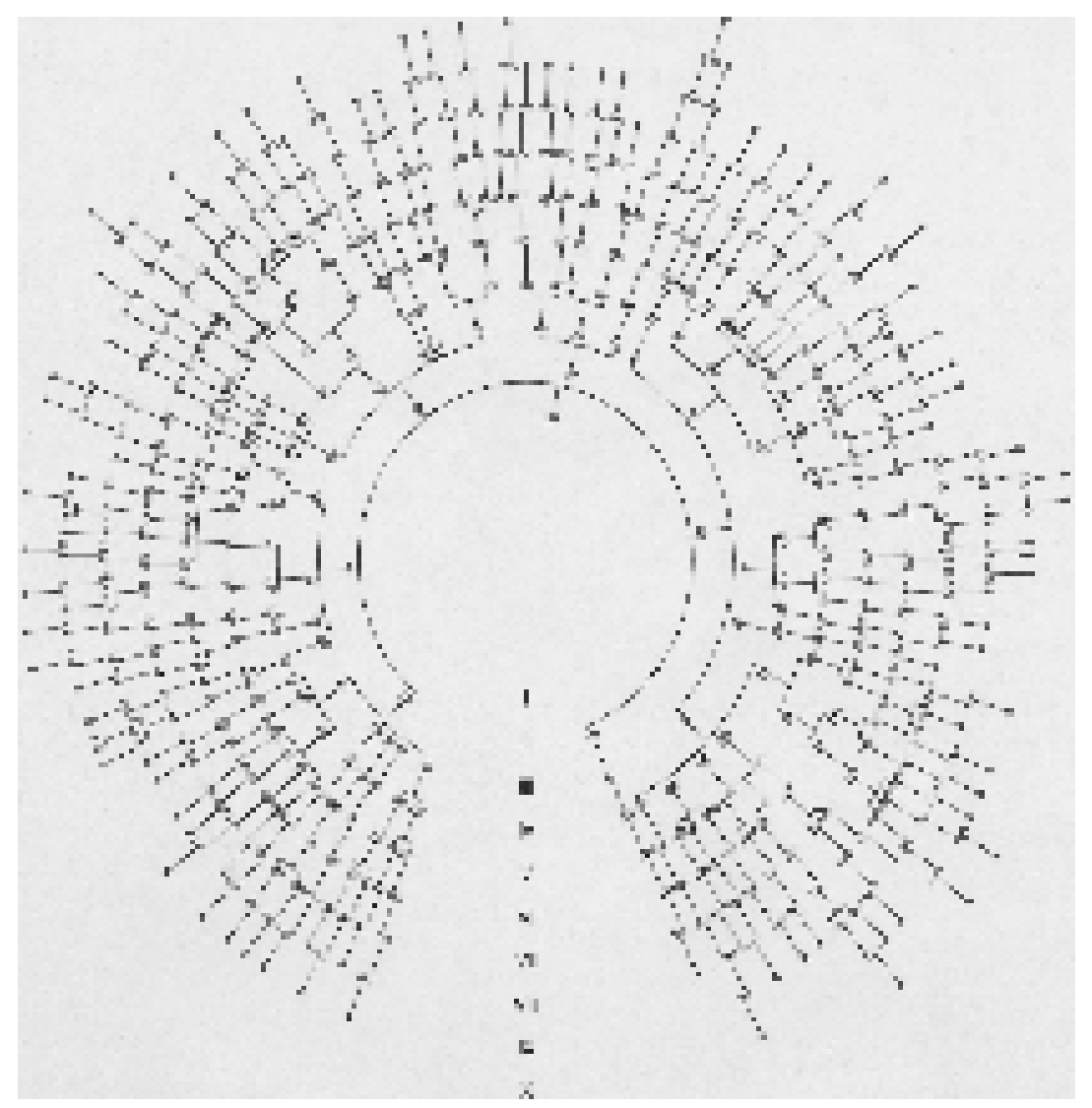

Source: (Pálsson 2002) “An asthma-pedigree with eleven generations”

Amongst affluent nations, other than perhaps Iceland, the United States, and a few other Anglophone ex-colonies, Britain by the early years of the current century stood out as odd. Whoever you voted for in 2001 or 2005 in Britain, you got the same bankers making policy. It was as if the affluent aristocrats of 1774 had been reincarnated and again asked "If all were alike opulent, who must be left to build and decorate our houses?” (Guyatt 2007) (page 178), 


\section{DORLING Social Evils}

all the dreamers and utopians in between having been forgotten. Social Darwinism had slowly and steadily caught up and then overtaken socialism as the revolutionary way to think. Entire nations sold their genetic heritage to companies trying to make a profit out of the differences that might exist between people (Figure 6). It was not thought that this work could be done for the common good without anyone's motive being greed. To think that was naïve. Be that naïve and you might come to believe that people would teach because they enjoyed teaching, fight poverty because they believed the fight worth fighting; work for respect and enjoyment and to contribute, not just for money; treat people who were sick because they wanted to make them better, not just for money; or be as naïve as to think that people could be happy with good enough shelter, not ever more greed. The mass idleness of the 1930s had been replaced by a mass prejudice from the 1990s onwards that suggested many people were shirkers; only money really motivated; only a very few were truly gifted and able and they were deserving of great reward, even at the expensive of not employing millions and millions seen as having low skills and little aptitude.

\section{Despair}

The penultimate social evil christened by William Beveridge was disease. The major infectious diseases that killed were largely eradicated in affluent countries before the onset of HIV. In affluent countries that disease was contained by the 1990s where there was money for drugs. However, rates of general illness, which fell to the 1970s, began to rise thereafter as more and more people found themselves feeling ill. These rates of mental illness became greatest in the most unequal of countries (see Figure 7). That international relationship is now seen as a near perfect correlation between the World Health Organisation's measure of the prevalence of mental illness (the \% people suffering) and the United Nation's Development Program's measure of the extent of inequality in each affluent country for which both measures have been taken (see Figure 7). Living in a more unequal society makes you more likely to suffer anxiety and depression. The two clear outliers in the study, as can be seen from Figure 7, Spain and Italy, are the two countries where income inequality ratios may not reflect inequalities in wealth so well because expectations to inherit property and support within families are higher in these countries than in the other ten shown in the Figure.

In response to rising rates of despair the government in Britain sought to bring in ever more restrictive social security measures to reduce the numbers of people claiming benefits, people just claiming in order to try to survive with a little dignity while too ill to work. It was obvious to most of those who were not bankers what would happen as a result: greater debt suffering and, eventually, destitution.

Here is just one example of the kind of comment posted in disbelief when the Social Security Green Paper of 2008 was published: "So what will happen? Well, the people who are faking it (and considering you get $£ 60$ a week and the stigma of being labelled disabled I 
think it will be considerably less than the tabloids may wish us to think) will just change their lies accordingly to pass the new assessment, whilst those genuinely ill will be bullied into unsuitable positions by private sector companies motivated by the bottom line” (comment posted on July 22 ' 08 , at 01:18am, by 'tangerinedream' ).

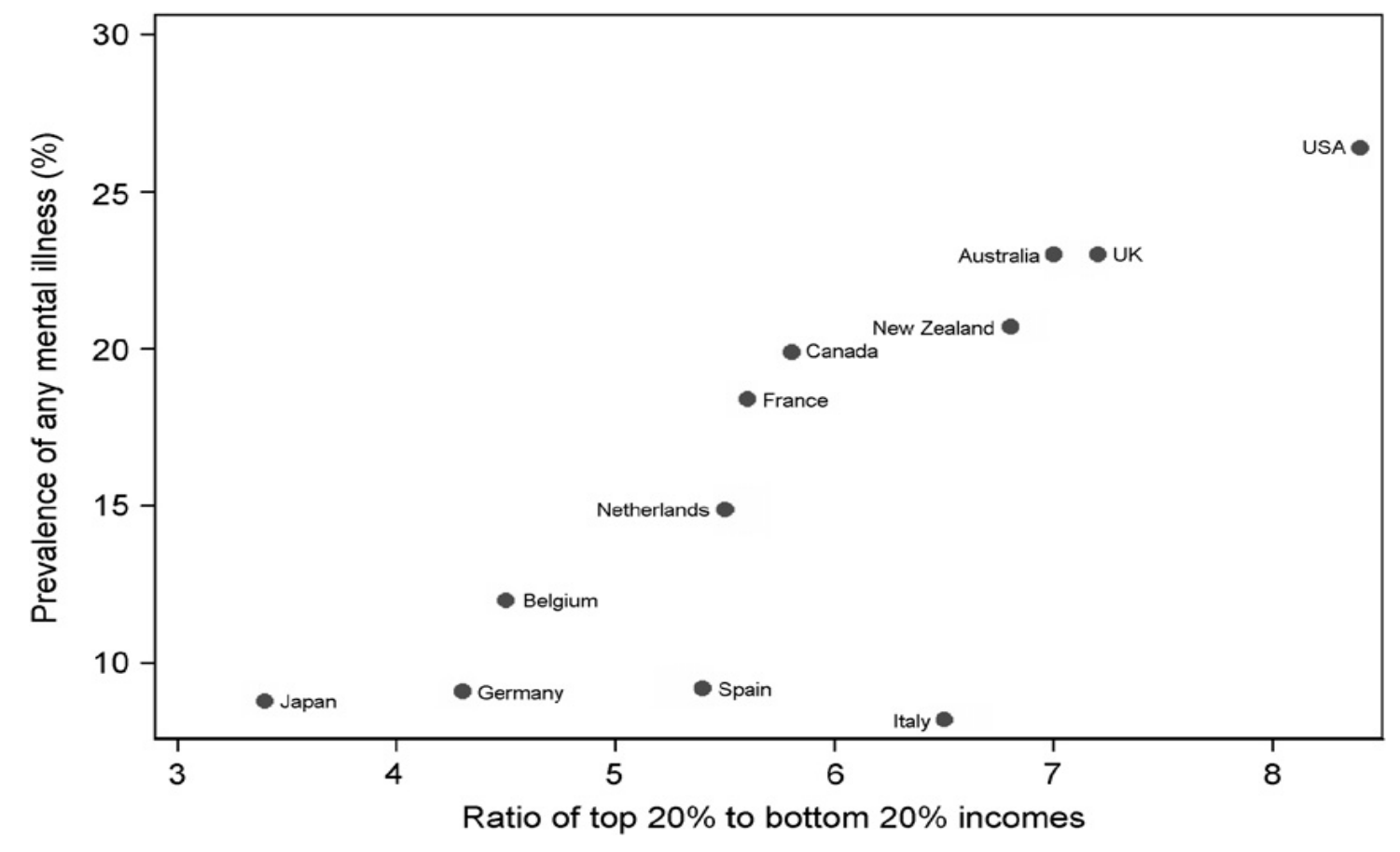

Figure 7: The Relationship between Social Inequality and Mental Well-being. Source: (Wilkinson and Pickett 2007)

The signs that government were planning to act so as to create yet more despair had been in the air for a few years (Dorling 2007). As economic recession loomed but the social policies of penalising those out of work to try ever harder did not change, it became clearer and clearer that there was just one hymn book they had to sing from, a book based on a single faith, the faith of efficiency, coercion, cajoling, god given potentials, of the new social evils. The health service had responded in the years leading up to this point by handing out more and more antidepressants. As Figure 8 shows, across the whole of Scotland the prescription of these drugs rose more than four fold between 1992 and 2006. This was partly due to the popularity of new SSRI drugs were medication peaks at ages 25-44 (NHS 2007) (page 6). Rates by 2006 exceeded 10\% of population in Argyll and Clyde (Greater Glasgow area) (page 12). The target is to stay at this, more than one in ten of all people popping pills to get through the day, 8.5\% of all in Scotland. 


\section{DORLING Social Evils}

Figure 8: Rate of Prescribing Antidepressants in Scotland 1992-2006.
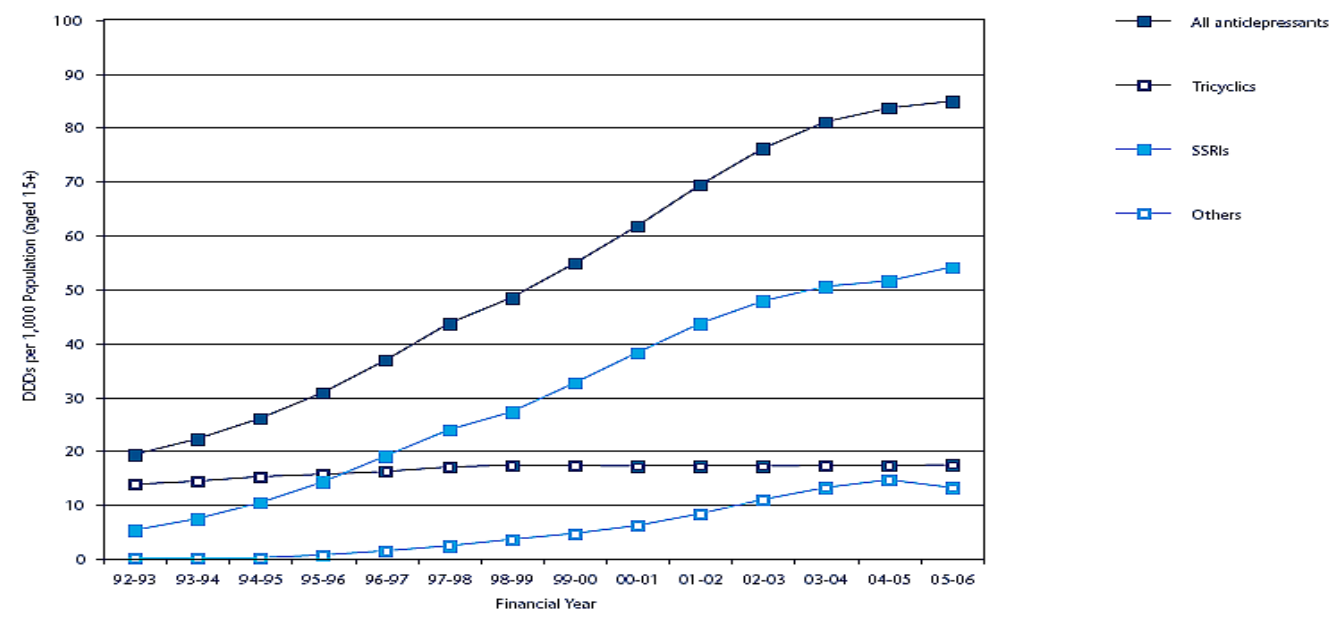

Source Figure 1.4 of (NHS 2007) defined daily doses (DDDs) per 1,000 population.

\section{Waste}

The last of William's five evils was squalor. By squalor he meant not having a decent home to live in, suffering from cold, degrading conditions; conditions which could foster disease and break human spirits. Today almost all of the poorest housing in Britain is better heated and carpeted than the best-off sheltered in 1942. The same is true across the affluent world, the worst-off tend to have access to more and better material goods now than the best-off had then, to better cars if they can just afford to run a car, to the occasional flight, to amounts of food that the affluent could not easily afford just a lifetime ago. We no longer suffer from too little to go round in the rich world. We do suffer from far higher levels of waste and greed than was seen in the 1940s. These are levels of waste and greed last experienced at the heights of profligacy seen over a century ago. But then, in general, we had far less to be wasteful of. We now have more rooms in our homes, per person, than has ever been the case before and more flats and houses per household too. And housing, just before the crash began, had never been so expensive. How did we get to the point that the scarcity of a necessity such as housing fell and its price rose? We got there by having faith in a misguided logic that supply and demand even out if you leave people alone to be privately greedy and selfish. We began to suffer from squalor of thought. We had suffered in this way before, a century ago (see Figure 9). We were only shaken out of that suffering by the deaths of millions of young men in the first global war (1914-1919), a decade of economic misery, general strikes, the worse economic crash ever experienced internationally (1929), another decade of economic misery, and another global war. It took all that to at last start seriously to confront our social evils just in Britain in 1942. 
Figure 9: The Pyramid of the Capitalist System at the Height of Inequality (1911)

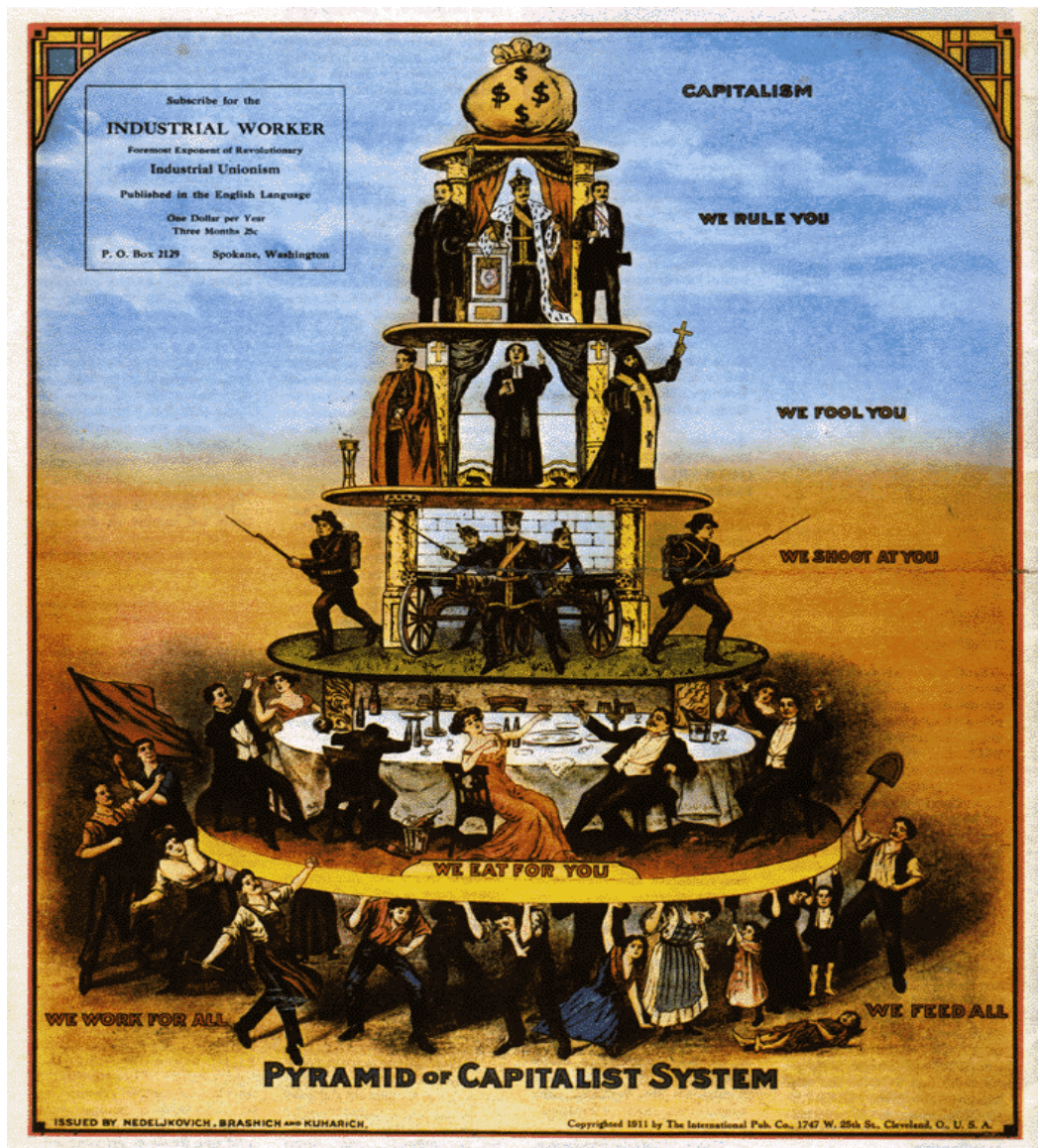

Source: [poster printed by the Industrial Workers of the World, dramatising economic inequality under capitalism and aiming to gain support for Industrial unionism.” Reproduced under the Wikipedia definition of "economic inequality" "Copyright 1911 by the International Pub Co. 747 W 25th St. Cleveland Ohio USA”).]

Today images, remarkably similar to those drawn a century ago, are constructed, but by organisations working under the auspices of the United Nations more often than Workers' Unions which used to arrange such drawing (see Figure 10). We draw parallels to the behaviour of the super rich then as to the super rich now. We note that most people have had to borrow greatly just to keep up with their neighbours. This is the case much more often in Britain than in mainland Europe as levels of inequality tend to be higher in Britain. "Average debts in Britain have increased by 50\% in real terms over the nine years 1997-2006”, and “...the UK accounted for half the credit card borrowing in the EU-15 in 2006” (Irvin 2008) (pages 170-171 and 189). 


\section{DORLING Social Evils}

Figure 10: The Mountain of the World System at the Height of Inequality (2007)

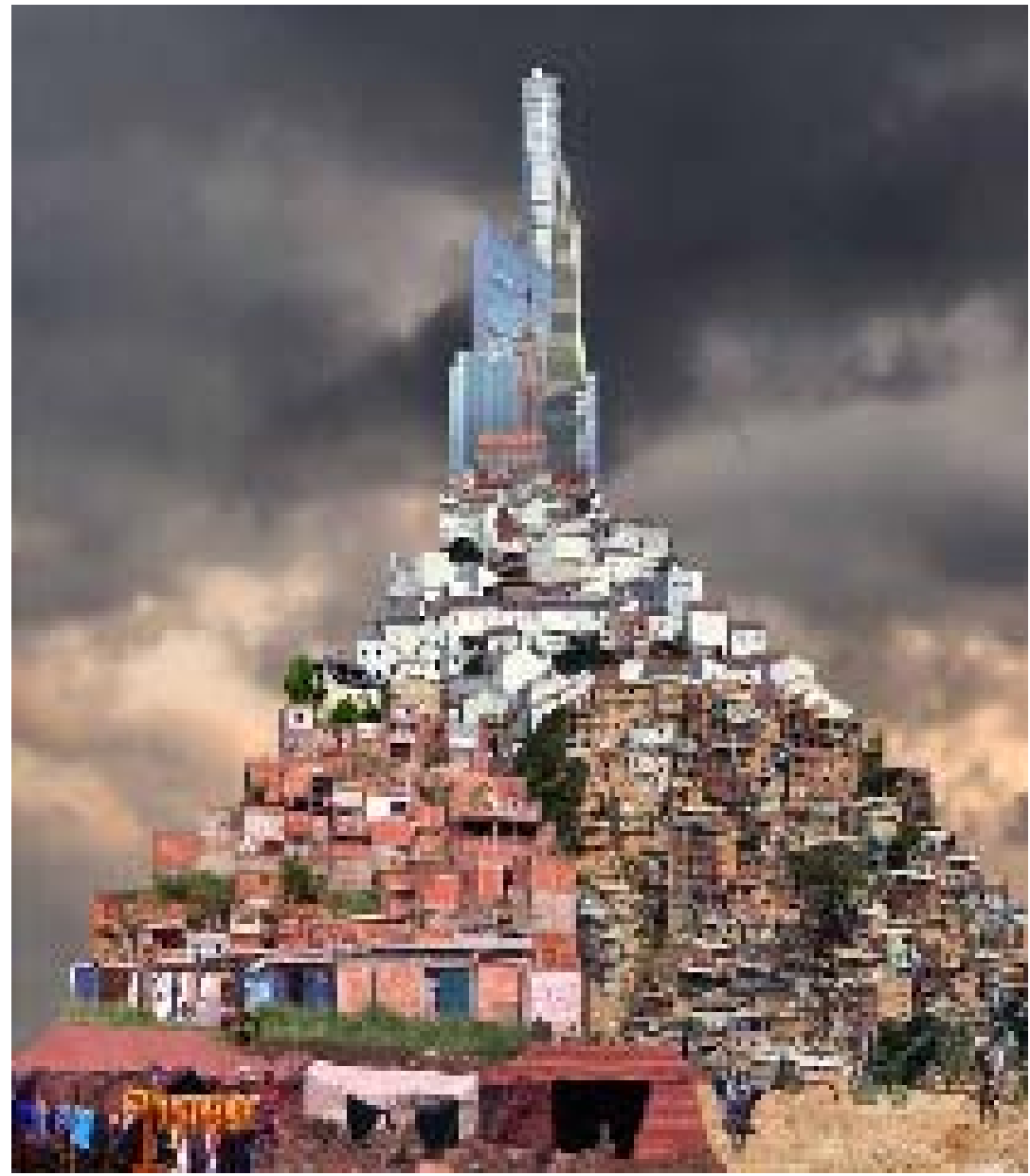

Source: Ehrenpreis, D. (2007). Poverty in Focus: the challange of inequality. Brasilia, International Poverty Centre. [Image source: Front page: Photomontage by Dr. Kurt Källblad, Malmö, Sweden, It includes parts of photos by George Bosela, Wellington, Ohio, USA; Bernhard Brück, Munich, Bavaria, Germany; David Davis, Union, Kentucky, USA; Projeto10 (Chico, Antonio, Tiago, Eduardo), Atibaia, São Paolo, Brazil; Kurt Källblad; Birgitta Lagerström, Brasilia, Brazil; and Xiskya Valladares, Madrid, Spain.]

By the start of the current century the behaviour of the very richest in the world was being described as akin to voyaging in search of a new Atlantis (Bauman 2006) (page 74, quoting Arundhati Roy). Ironically, two years later a supposedly seven star hotel was opened in a Middle East state and given the name Atlantis. If you are super rich you need never stay in 
one of your many homes. As it opened to one of the most spectacular fireworks display the world has ever seen, banks began to go bust worldwide at a rate not experienced since 1929.

\section{Conclusion}

The old social evils were clear binary divisions of the have-nots from the haves: those who were or were not ignorant; those who were poor; who were idle; or suffered from disease; who lived in squalor. They were drawn as characters of a black and white world, apt for a time when there was not enough to go round, only a very few got fat, and many suffered as a result of too few resources. In affluent nations those divides have now gone, stretched out instead to multiple continuums of various injustices. Each continua needs a new name as an injustice caused by poor distribution of abundant resources is very different from an evil caused by not carefully and efficiently distributing scarce resources.

Elitism, exclusion, prejudice, despair and waste: new social evils, the metamorphosed shapes now of ignorance, want, idleness, disease and squalor? When people are presented with these suggestions the word they most object to is 'evil', 'injustice' is usually preferred, and they tend to prefer 'greed' to 'waste'. Waste is less pejorative, but 'injustice' in place of 'evil' I can understand. There are greater evils than the snobbery of elitism; there are still much worse things done to people than their exclusion from the norms of society (although that is often the precursor); prejudice is unjust, it is particular prejudices that are most evil; despair is a terrible injustice to bear but no one sought deliberately to spread or maintain it as far as I know in recent years; waste is a terrible injustice given how many have so little in the world, but I would not label everyone who is wasteful evil. Very few in affluent countries would be left who could be viewed as even slightly good if so.

It is after the event that what was wrong in the past most clearly became visible. Who now would argue that most children did not merit a secondary education? Who would now claim that poverty was the natural lot of the majority? Who would state that idleness, while unfortunate, was just the natural condition for many people in young adulthood, the best that could be expected? Who would claim that diseases were simply acts of god only to be avoided by those rich enough to pay for physicians? Who would say that squalor was a necessary condition of much human life? Hardly anyone would today defend the five old social evils.

In contrast, notch every case up a slot and you can see that injustices today are supported often by a majority of those who now have most. Simply ask the following questions to indentify those who support injustice today: Who then, today, thinks that it would be profligate and wasteful to provide free territory education to all young adults? Who believes that only those who 'work hard' should be allowed to enjoy the comforts of life, others don't deserve such mollycoddling? Who believes that some people are naturally a little more talented than others, got it from their father's side where they were always 'good with 


\section{DORLING Social Evils}

numbers' and not 'a bad lot'? Who believes that people should just pull themselves together, what is all this despair when they have never had it so good? Who believes that the market will regulate our behaviour, control our consumption, stop us being wasteful, and allocate resources efficiently? Enough people in power still believe all these things for social injustice to prevail. But every day there are fewer and fewer who really have faith in such injustice. Many pretend to still believe, more find it hard to do even that, most no longer believe, some are starting to suggest many alternatives to injustice (Magnason 2008), but it is hard to come to terms with the suggestion that what you once thought was straight-thinking is all warped, hard to learn that the past you had been taught was of another place.

Between 1914 and 1942: pandemic, war, crash, depression, racism and perhaps not a little fear of communism conspired so that what it had been impossible to suggest at the start of that period became the accepted wisdom by the end. However, the eradication of most of the worse manifestations of those of binary social evils was only a success story (even in its own terms) if the exploitation of the poor majority of the world was ignored. Those additional resources that made it possible to end the most base ignorance, want, idleness, disease and squalor came often at the expense of exacerbating such evils elsewhere in the world (Davis 2000). The tragedy of today, and if you are optimistic one possible route to salvation, is that even ignoring the poor majority of the world's population those evils have not really been overcome in rich nations (Connelly 2008), rather they have metamorphosed into new injustices. By 2009 we again had unusual numbers of wars, economic crashes, the beginning of recession, and good reasons not to forget (Field 1999). Often this is not to forget old lessons that we can now learn in much greater numbers: We have enough for all our needs, but we have yet to recognise how the old evils have turned into new injustices, still justified in the minds that forgot, never knew, were never told (Wilkinson and Pickett 2009). If exploiting the poor of the majority of the world does not end injustice in affluent nations (Hayter 2004), if putting even a few in affluent nations on high pedestals does not even appear to make them that happy (Gilbert 2006), then if we are at all able to act in concert in large groups and escape our individual stupidity the mappings will change within a generation again (Burns 2007). It is precisely because the present is now so different from our recent past that we should not expect the future to be more of the same. All that it takes to see how easy it could be to change lies in the mind (Dorling, 2010).

\section{References}

Ball, S. J. (2008), The Education Debate. Bristol, Policy Press.

Bauman, Z. (2006), Liquid Fear. Cambridge, Polity Press.

BBC (2008) Jobless Highest Rise in 17 years: Report 15th October: http://news.bbc.co.uk/2/hi/business/7670800.stm 
Burns, J. (2007), The Descent of Madness: Evolutionary Origins of Psychosis and the Social Brain. Hove, Routledge.

Connelly, M. (2008). Fatal Misconception: The Struggle to Control World Population. Massachusetts, Harvard University Press.

Davis, M. (2000), The Origin of the Third World, Antipode 32, 48-89.

Dixon, M. (2005), Brave New Choices? Behavioural Genetics And Public Policy: A Discussion Document, London, Institute of Public Policy Research.

Dorling, D. (2007), Guest Editorial: The Real Mental Health Bill, Journal of Public Mental Health 6, 6-13.

Dorling, D., Rigby, J., Wheeler, B., Ballas, D., Thomas, B., Fahmy, E., Gordon, D., and Lupton, R (2007), Poverty, Wealth and Place in Britain, 1968 to 2005. Bristol, Policy Press.

Dorling, D. (2010), Injustice: Why Social Inequalities Persist. Bristol: Policy Press.

Field, P. (1999), The Anti-Roads Movement: The Struggle of Memory against Forgetting. Storming the Millennium: The New Politics of Change, T. Jordan and A. Lent. London, Lawrence and Wishart: 68-79.

Freud, D. (2007). Reducing Dependency, Increasing Opportunity: Options for The Future of Welfare to Work: an Independent Report to The Department for Work and Pensions. London, DWP.

Gilbert, D. (2006), Stumbling on Happiness, London, Harper Collins.

Guyatt, N. (2007), Have a Nice Doomsday: Why Millions of Americans are Looking Forward to the End of theWworld. London, Ebury (Random House).

Hayter, T. (2004), Open Borders: The Case Against Immigration Control,. London, Pluto Press.

Irvin, G. (2008), Super Rich: The Rise of Inequality in Britain and the United States, Cambridge, Polity.

Magnason, A. S. (2008), Dreamland: A Self-Help Manual for a Frightened Nation, London, Citizen Press Ltd.

Mazower, M. (2004), Salonica, City of Ghosts: Christians, Muslims and Jews 1430-1950, London, HaperCollins.

NHS (2007), NHS Quality Improvement Scotland: Clinical Indicators 2007, Glasgow, NHS Quality Improvement Scotland.

Pálsson, G. (2002), The Life of Family Trees and the Book of Icelanders, Medical Anthropology 21, 337-367.

Toynbee, P. (2008). Labour's sin-eater has now neutralised welfare reform: James Purnell's radical proposals have shot the Tory fox, but at the expense of those who can least afford a cut. The Guardian. London. 22 July. 


\section{DORLING Social Evils}

Wilkinson, R. and K. Pickett (2009), The Spirit Level: Why More Equal Societies Almost Always Do Better, London, Allen Lane.

Wilkinson, R. G. and K. E. Pickett (2007), The problems of relative deprivation: Why some societies do better than others, Social Science and Medicine, 65, 1965-1978.

Wintour, P. and P. Curtis (2008), 'McQualification' derided as Brown launches training reforms, The Guardian, London, 29 January. 